\title{
Noncalcemic Vitamin D Hydroxyderivatives Inhibit Human Oral Squamous Cell Carcinoma and Down-regulate Hedgehog and WNT/ $\beta$-Catenin Pathways
}

\author{
ALLEN S.W. OAK ${ }^{1 *}$, GEORGETA BOCHEVA ${ }^{2 *}$, TAE-KANG KIM ${ }^{1}$, ANNA A. BROŻYNA ${ }^{1,3}$, \\ ZORICA JANJETOVIC ${ }^{1}$, MOHAMMAD ATHAR ${ }^{1}$, ROBERT C. TUCKEY ${ }^{4}$ and ANDRZEJ T. SLOMINSKI ${ }^{1,5}$ \\ ${ }^{1}$ Department of Dermatology, University of Alabama at Birmingham, Birmingham, AL, U.S.A.; \\ ${ }^{2}$ Department of Pharmacology and Toxicology, Medical University of Sofia, Sofia, Bulgaria; \\ ${ }^{3}$ Department of Human Biology, Institute of Biology, Faculty of Biological and Veterinary Sciences, \\ Nicolaus Copernicus University, Torun, Poland; \\ ${ }^{4}$ School of Molecular Sciences, University of Western Australia, Perth, WA, Australia; \\ ${ }^{5}$ VA Medical Center, Birmingham, AL, U.S.A.
}

\begin{abstract}
Background/Aim: The hormonally-active form of vitamin $D, 1,25(\mathrm{OH})_{2} D_{3}$, demonstrated activity against oral squamous cell carcinoma (OSCC). Cytochrome P450scc (CYP11A1)-derived vitamin $D$ hydroxyderivatives, such as $2 \mathrm{O}(\mathrm{OH}) \mathrm{D}_{3}$ and $1,2 \mathrm{O}(\mathrm{OH})_{2} \mathrm{D}_{3}$, have overlapping beneficial effects with $1,25(\mathrm{OH})_{2} \mathrm{D}_{3}$ without causing hypercalcemia. This study sought to determine (i) whether $20(\mathrm{OH}) D_{3}$ and $1,2 \mathrm{O}(\mathrm{OH})_{2} \mathrm{D}_{3}$ exhibit antitumor effects against OSCC comparable to those of $1,25(\mathrm{OH})_{2} \mathrm{D}_{3}$ and (ii) whether these effects may stem from down-regulation of sonic hedgehog (SHH) or WNT/ $\beta$-catenin signaling pathways. Materials and Methods: Effects on CAL-27 cells were assessed by 3-(4,5dimethylthiazol-2-yl)-5-(3-carboxymethoxyphenyl)-2-(4sulfophenyl)-2H-tetrazolium inner salt and spheroid assays. Signaling pathways were assessed by immunofluorescence and western blotting. Results: $20(\mathrm{OH}) \mathrm{D}_{3}$ and $1,2 \mathrm{O}(\mathrm{OH})_{2} \mathrm{D}_{3}$ inhibited the growth of CAL-27 and demonstrated inhibition of WNT/ $\beta$-catenin and the SHH signaling as evidenced by down-regulation of nuclear translocation of glioma-associated oncogene 1(GLII) and $\beta$-catenin. Conclusion: Noncalcemic
\end{abstract}

This article is freely accessible online.

*These Authors contributed equally to this study.

Correspondence to: Andrzej T. Slominski, MD, Ph.D., 1670 University Boulevard, Volker Hall 476C, Birmingham, AL 352940019, U.S.A. Tel: +1 2059345245, Fax: +1 2059960302, e-mail: aslominski@uabmc.edu

Key Words: Oral squamous cell carcinoma, vitamin D, sonic hedgehog signaling, $\mathrm{SHH}, \mathrm{WNT} / \beta$-catenin signaling, 20-hydroxyvitamin $\mathrm{D}_{3}$, 1,20-dihydroxyvitamin $\mathrm{D}_{3}$. vitamin $D$ hydroxyderivatives demonstrated antitumor activities against OSCC comparable to those of $1,25(\mathrm{OH})_{2} \mathrm{D}_{3}$. Their activities against $\mathrm{SHH}$ and the $W N T / \beta$-catenin pathways provide insight for a possible target for OSCC treatment.

Oral and pharyngeal cancer combined represent the sixth most common cancer globally. The estimated global incidence of oral cancer alone is 275,000, and about twothirds of these occur in developing nations (1). The estimated incidence of oral cavity and oropharyngeal cancer in the USA was 53,000 in 2019 (2), and more than 90\% of these were squamous cell carcinomas (OSCCs) (3). Greater than $50 \%$ of OSCCs arise from the tongue and the floor of the mouth but they can arise from anywhere within the mouth (4). CAL-27 is an oral adenosquamous cell carcinoma line derived from the tongue of a 56-year-old man with poorly differentiated disease $(5,6)$, and it is frequently used for in vitro studies of OSCC.

Systemic treatment options for OSCCs include docetaxel, cisplatin and fluorouracil, as well as cetuximab, an epidermal growth factor receptor (EGFR) inhibitor (7). Loss of cyclindependent kinase inhibitor $2 \mathrm{~A}(C D K N 2 A)$, tumor protein p53 (TP53), transforming growth factor beta receptor 2 (TGFBR2)/ SMAD (fusion of Caenorhabditis elegans Sma and Drosophila Mothers against decapentaplegic) family member 4 (SMAD4) have been implicated in the molecular pathogenesis of OSCC. Abnormal expression of genes associated with tumor survival, such as EGFR, phosphatidylinositol-4,5-bisphosphate 3-kinase catalytic subunit alpha (PIK3CA) and caspase 8 (CASP8), have also been implicated (8).

Recently, members of the hedgehog signaling pathway have been identified as being up-regulated in OSCC. Sonic hedgehog $(\mathrm{SHH})$, a ligand that binds to patched, was found 

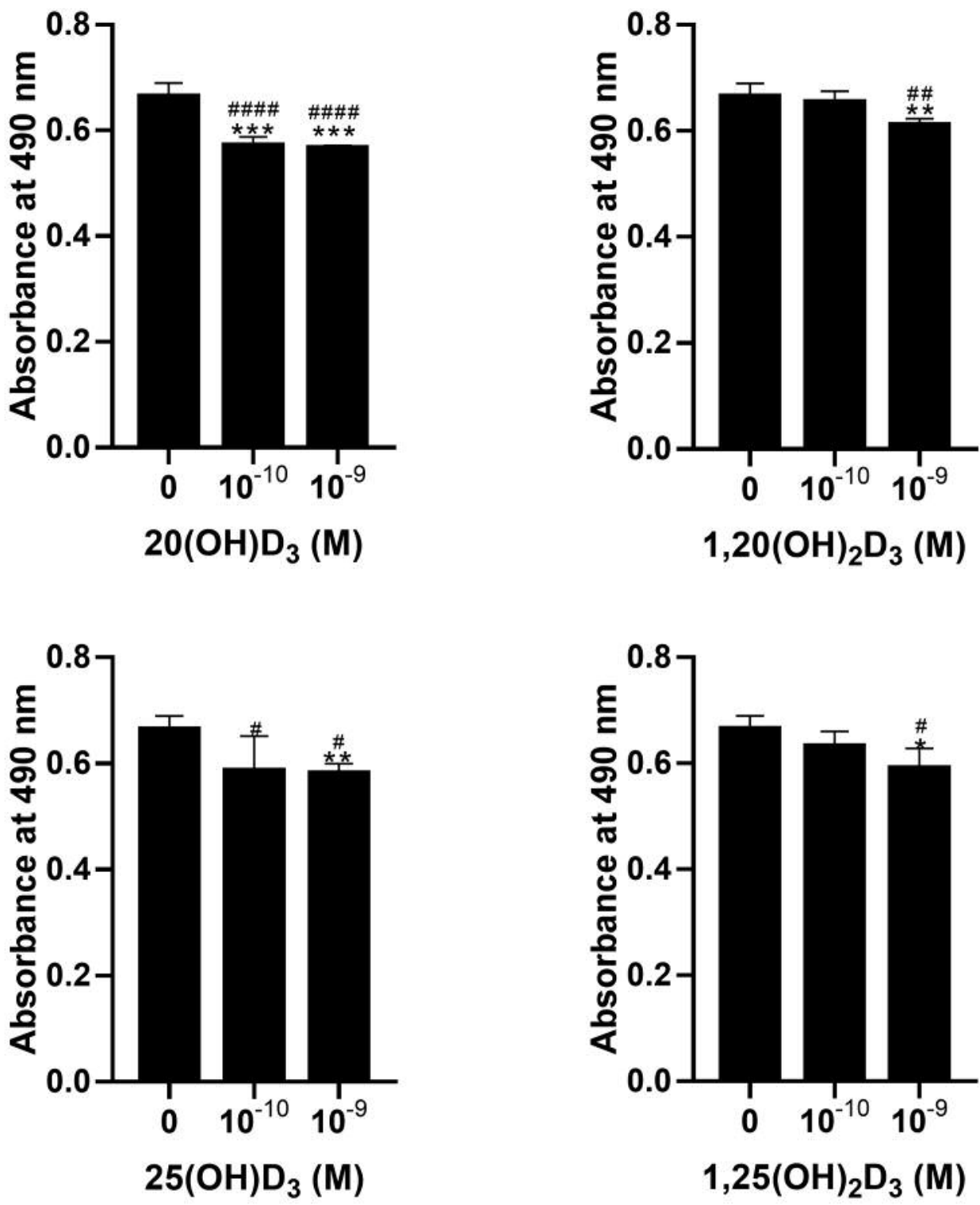

Figure 1. Hydroxyderivatives of vitamin $\mathrm{D}, 2 \mathrm{O}(\mathrm{OH}) \mathrm{D}_{3}$ and $1,2 \mathrm{O}(\mathrm{OH})_{2} \mathrm{D}_{3}$, exhibit antiproliferative effects against human oral squamous cell carcinoma cells at levels comparable to those of $25(\mathrm{OH}) \mathrm{D}_{3}$ and $1,25(\mathrm{OH})_{2} \mathrm{D}_{3} . \mathrm{CAL}-27$ cells were treated with vitamin D hydroxyderivatives in $10 \%$ charcoal-treated fetal bovine serum for 48 h. 3-(4,5-Dimethylthiazol-2-yl)-5-(3-carboxymethoxyphenyl)-2-(4-sulfophenyl)-2H-tetrazolium, inner salt/phenazine methosulfate solution was added $3 \mathrm{~h}$ prior to absorbance measurement. Data are presented as the mean $\pm S D(n \geq 3)$. Significantly

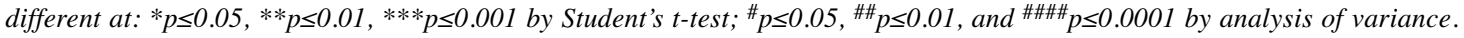

to be highly up-regulated in human tongue OSCC, and other members of the hedgehog signaling pathway, such as patched, glioma-associated oncogene 1 (GLI1) and GLI2, were found to be up-regulated in microvascular cells in the tumor invasive front (9). A significantly higher expression of SHH by immunohistochemistry was identified from patient biopsy samples of OSCC, and the pattern of expression highlighted increased staining in the invasive tumor front of well-differentiated OSCCs (10).
The WNT/ $\beta$-catenin pathway, a regulator of key molecular functions such as proliferation, differentiation and stem cell renewal, had also been implicated in migration and invasion of OSCC. OSCC cells with mutated $\beta$-catenin exhibited increased invasion and migration in transwell chamber assay, and increased expression of matrix metalloproteinase-7 identified by reverse transcriptase-polymerase chain reaction (11).

Up-regulation of vitamin D-binding protein was identified in OSCC (12), and a functional single nucleotide polymorphism 
in the gene for vitamin $\mathrm{D}$ receptor $(V D R)$ was associated with reduced overall survival in a study examining 110 patients with OSCC and 122 healthy controls (13). Furthermore, higher expression of VDR was seen in squamous intraepithelial neoplasia I-III, as well as in OSCC, compared to that of normal oral mucosa (14). It had also been reported that eldecalcitol, an analog of $1,25(\mathrm{OH})_{2} \mathrm{D}_{3}$, inhibits oral squamous cell carcinoma in vitro, and causes downregulation of the nuclear factor of the $\mathrm{K}$-chain in B-cells (NF-kB) pathway (15). It was also demonstrated that calcitriol treatment was able to partially reverse cisplatin sensitivity in OSCCs (16).

Based on prior results reporting the activity of $1,25(\mathrm{OH})_{2} \mathrm{D}_{3}$ activities against OSCC, it was hypothesized that novel noncalcemic hydroxyderivatives of vitamin $\mathrm{D}, 20(\mathrm{OH}) \mathrm{D}_{3}$ and $1,20(\mathrm{OH})_{2} \mathrm{D}_{3}$, will have similar antitumor effects. These novel secosteroids inhibit proliferation of keratinocytes, stimulate their differentiation, and downregulate the NF-kB pathway (1719). Both hydroxyderivatives are metabolites of cytochrome P450scc (CYP11A1), the first enzyme of the steroid biosynthetic pathway in mitochondria, which besides cholesterol can also hydroxylate vitamins $\mathrm{D}_{3}$ and $\mathrm{D}_{2}$ and their precursors 7-dehydrocholesterol and ergosterol (20-23), respectively. CYP11A1 and its products are endogenously present in human skin; they have been identified in cultured keratinocytes, dermal fibroblasts and the epidermis $(20,21,24$, 25). Many novel secosteroids derived from the CYP11A1mediated pathway inhibit proliferation and induce differentiation with efficacies comparable to those of $1,25(\mathrm{OH})_{2} \mathrm{D}_{3}$ and $25(\mathrm{OH}) \mathrm{D}_{3}(7)$. Two best characterized of these novel secosteroids, $20(\mathrm{OH}) \mathrm{D}_{3}$ and $20,23(\mathrm{OH})_{2} \mathrm{D}_{3}$, are noncalcemic at pharmacological doses $(26,27)$. Administration of a high dose $(30 \mu \mathrm{g} / \mathrm{kg})$ of $20(\mathrm{OH}) \mathrm{D}_{3}$ for 14 days to C57BL/6 mice did not raise the serum calcium level or cause any toxicity detectable via histological analysis or serum chemistry (27). On the other hand, $1,25(\mathrm{OH})_{2} \mathrm{D}_{3}$ induced renal and cardiac calcium deposits at $0.8 \mu \mathrm{g} / \mathrm{kg}(28)$.

\section{Materials and Methods}

Secosteroids. $20(\mathrm{OH}) \mathrm{D}_{3}$ and $1,20(\mathrm{OH})_{2} \mathrm{D}_{3}$ were enzymatically synthesized with a reconstituted CYP11A1-mediated system using vitamin $\mathrm{D}_{3}$ and $1 \alpha$-hydroxyvitamin $\mathrm{D}_{3}$ from Sigma-Aldrich (St. Louis, MO, USA) as substrates, respectively $(29,30)$. Both were purified by thin-layer chromatography, followed by reversed-phase high-performance liquid chromatography. Their molecular identities were confirmed by mass and UV spectra as described previously (31), and were stored until use at $-80^{\circ} \mathrm{C}$. Commercially available $1,25(\mathrm{OH})_{2} \mathrm{D}_{3}$ and $25(\mathrm{OH}) \mathrm{D}_{3}$, were purchased from Sigma-Aldrich.

Proliferation assay. CAL-27 cells, purchased from the American Type Culture Collection (Manassas, VA, USA), were cultured in Dulbecco's modified Eagle's medium (DMEM) supplemented with $0.5 \%$ penicillin/streptomycin and $10 \%$ fetal bovine serum (FBS) in a humidified incubator with $5 \% \mathrm{CO}_{2}$ at $37^{\circ} \mathrm{C}$. CAL-27 cells were plated on 96-well plates with $10 \%$ charcoal-treated FBS (Atlanta

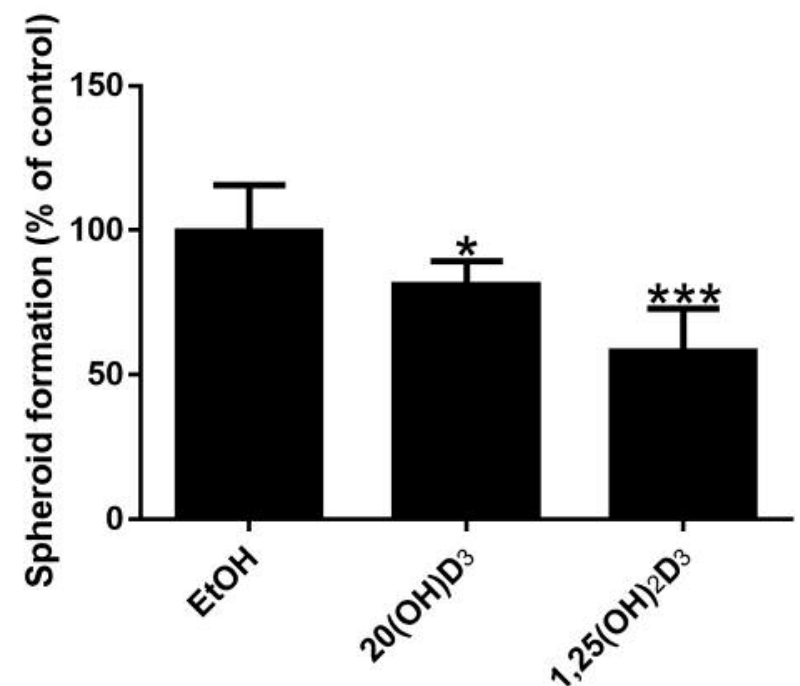

Figure 2. Hydroxyderivative of vitamin $\mathrm{D}, 2 \mathrm{O}(\mathrm{OH}) \mathrm{D}_{3}$, inhibits spheroid formation by CAL-27 cells. CAL-27 cells were seeded at 500 cells/well and treated with $10^{-7} \mathrm{M}$ of $2 \mathrm{O}(\mathrm{OH}) \mathrm{D}_{3}, 1,25(\mathrm{OH})_{2} \mathrm{D}_{3}$ or vehicle control (ethanol, $\mathrm{EtOH}$ ), and incubated for 7 days at $37^{\circ} \mathrm{C}$. Spheroids that were greater than $50 \mu \mathrm{m}$ were counted. Data are presented as mean $\pm S D(n \geq 4)$. Significantly different at: ${ }^{*} p \leq 0.05$, and ${ }^{* * *} p \leq 0.001$ by Student's $t$-test.

Biologicals, Inc., Flowery Branch, GA, USA). After an overnight incubation, the medium was switched to serum-free medium to synchronize the cells for the subsequent $24 \mathrm{~h}$. Cells were then treated with secosteroids in $10 \%$ charcoal-treated FBS and $0.5 \%$ penicillin/streptomycin for 48 h. 3-(4,5-Dimethylthiazol-2-yl)-5-(3carboxymethoxyphenyl)-2-(4-sulfophenyl)-2H-tetrazolium, inner salt (MTS)/phenazine methosulfate (PMS) solution (Promega, Madison, WI, USA) was added per the manufacturer's instructions. After incubation at $37^{\circ} \mathrm{C}$ for $3 \mathrm{~h}$, the absorbance at $490 \mathrm{~nm}$ was recorded using a Cytation 5 Cell Imaging Multi-Mode Reader (Winooski, VT, USA).

Immunofluorescence microscopy. CAL-27 cells (40,000 cells in 200 $\mu 1)$ were placed on autoclaved glass coverslips on a 6 -well plate. After $4 \mathrm{~h}$ in $37^{\circ} \mathrm{C}$, the slides were incubated overnight at $37^{\circ} \mathrm{C}$ with $2 \mathrm{ml}$ of DMEM containing $0.5 \%$ penicillin/streptomycin. They were then treated with $20(\mathrm{OH}) \mathrm{D}_{3}, \quad 1,20(\mathrm{OH})_{2} \mathrm{D}_{3}, \quad 25(\mathrm{OH}) \mathrm{D}_{3}$, $1,25(\mathrm{OH})_{2} \mathrm{D}_{3}$ or vehicle (ethanol) at $10^{-7} \mathrm{M}$ in DMEM with $0.5 \%$ bovine serum albumin (bovine serum albumin; Sigma-Aldrich), for $24 \mathrm{~h} \mathrm{at} 37^{\circ} \mathrm{C}$. The cells were fixed with $2 \mathrm{ml}$ of $4 \%$ paraformaldehyde for $15 \mathrm{~min}$, then in $0.5 \%$ Triton $\mathrm{X}-100$ in phosphate-buffered saline (PBS) for $5 \mathrm{~min}$. They were then washed three times in PBS, followed by blocking for $1 \mathrm{~h}$ at $37^{\circ} \mathrm{C}$. Subsequently, the cells were incubated with mouse antibodies against $\beta$-catenin (BD Transduction Laboratories, Franklin Lakes, NJ, USA) or rabbit antibodies against GLI1 (Novus, St. Louis, MO, USA), at a dilution of 1:200 in $2 \%$ BSA in PBS, at $4^{\circ} \mathrm{C}$ overnight. Stained cells were washed in PBS 3 times, then respectively treated with secondary anti-mouse antibodies and anti-rabbit antibodies at 1:200 (Santa Cruz, Dallas, TX, USA). These cells were mounted using propidium iodide (Vector Laboratories, Burlingame, CA, 


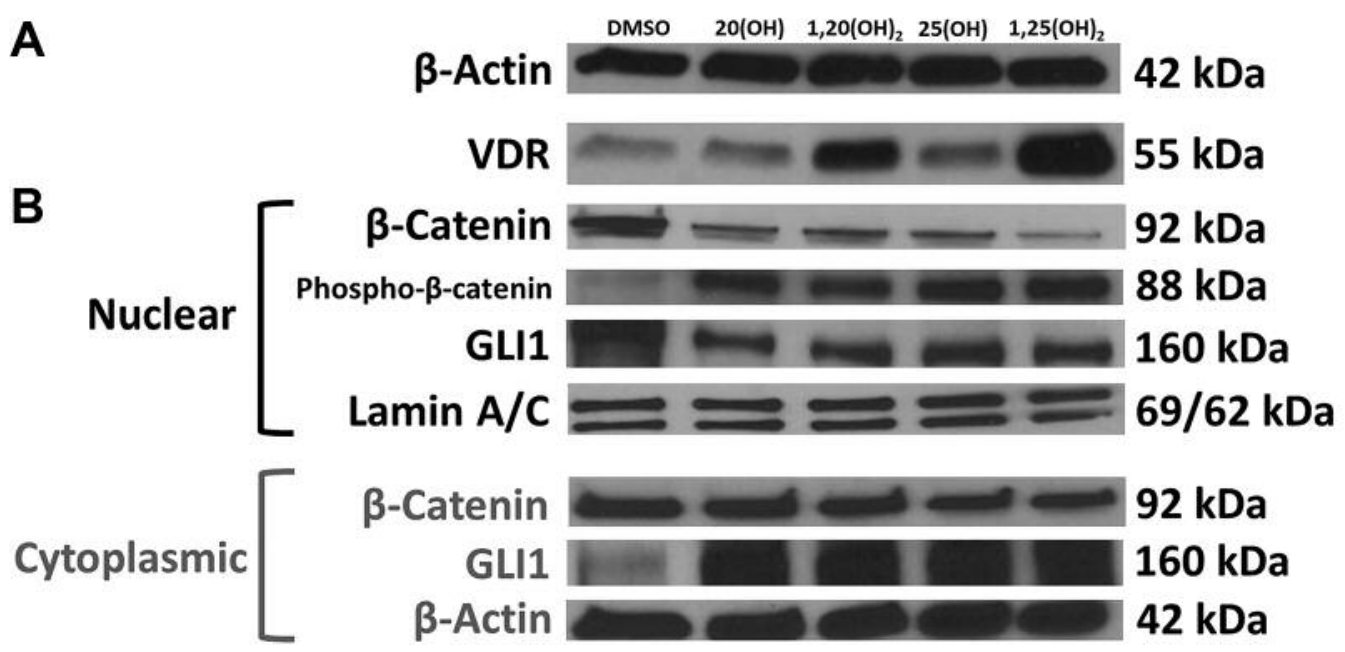

Figure 3. Western blot analysis of the effects of secosteroids on the levels of vitamin D receptor (VDR) and nuclear and cytoplasmic forms of gliomaassociated oncogene 1 (GLII) and $\beta$-catenin. A: CAL-27 cells were incubated with hydroxyvitamin D derivatives (10-7 M for 24 h) and the level of $V D R$ was measured in total cell extracts. Lamin $\mathrm{A} / \mathrm{C}$ and $\beta$-actin served as loading controls. B: Cells were incubated for $24 \mathrm{~h}$ with $10^{-7} \mathrm{M}$ of $20(\mathrm{OH}) \mathrm{D}_{3}$, $1,20(\mathrm{OH})_{2} \mathrm{D}_{3}, 25(\mathrm{OH}) \mathrm{D}_{3}$ or $1,25(\mathrm{OH})_{2} \mathrm{D}_{3}$ and nuclear and cytoplasmic levels of GLII and $\beta$-catenin were determined. DMSO: Dimethyl sulfoxide.

USA) as counterstain, and examined using a KEYENCE America BZ-X710 Fluorescence Microscope. The images were subsequently analyzed to calculate the corrected total cell fluorescence $[\mathrm{CTCF}=$ integrated density $-($ area of selected cell $\times$ mean of background fluorescence)] using ImageJ (National Institutes of Health, Bethesda, MD, USA).

Spheroid formation. The spheroid formation ability of cells was assessed according to the protocol of Johnson and colleagues (32). CAL-27 cells were seeded at 1,000 cells/well on an ultra-low attachment 96 -well plate, then treated with $10^{-7} \mathrm{M}$ of $20(\mathrm{OH}) \mathrm{D}_{3}$, $1,25(\mathrm{OH})_{2} \mathrm{D}_{3}$ or vehicle (ethanol), and incubated in medium enriched with B27 Supplement (Thermo Fisher Scientific, Waltham, MA, USA), bFGF, EGF, insulin and BSA (Sigma-Aldrich) for 7 days at $37^{\circ} \mathrm{C}$. Spheroids that were greater than $50 \mu \mathrm{m}$ were counted using Cytation 5 Cell Imaging Multi-Mode Reader and statistically analyzed.

Western blot analysis. For analysis of $\beta$-catenin, phosphorylated $\beta$ catenin (Invitrogen, Carlsbad, CA, USA) and GLI1 expression, CAL-27 cells were incubated with $10^{-7} \mathrm{M}$ of $20(\mathrm{OH}) \mathrm{D}_{3}$, $1,20(\mathrm{OH})_{2} \mathrm{D}_{3}, \quad 25(\mathrm{OH}) \mathrm{D}_{3}, \quad 1,25(\mathrm{OH})_{2} \mathrm{D}_{3}$ or vehicle (dimethyl sulfoxide) for $24 \mathrm{~h}$ at $37^{\circ} \mathrm{C}$ prior to extraction of nuclear proteins. Protein extraction was carried out with Nuclear Extract kit (Active Motif, Carlsbad, CA, USA) according to the manufacturer's protocol. For analysis of VDR expression, extraction was carried out with RIPA buffer and proteins were further incubated for $3 \mathrm{~h}$ with anti-VDR (D-6; Santa Cruz Biotechnology). Primary antibody concentrations used for detection of $\beta$-catenin (E-5; Santa Cruz Biotechnology), phosphorylated $\beta$-catenin (Invitrogen), GLI1 and VDR were $1: 1,000,1: 1,000,1: 1,000$ and 1:200, respectively. Antibody to lamin A/C (N-18; Santa Cruz Biotechnology) was used at $1: 200$ as a control for nuclear proteins and antibody to $\beta$-actin at 1:20,000 (BD Transduction Laboratories, Franklin Lakes, NJ, USA) for cytoplasmic proteins and the non-fractionated mix for the VDR western blot.

Statistical analysis. Data analysis was performed using Graphpad Prism 7 (GraphPad Software, San Diego, CA, USA). Data are presented as means \pm SD. They were analyzed with unpaired twotailed student's $t$-test or with one-way ANOVA using Dunnett's Multiple Comparison post hoc test (for more than two groups). Statistically significant differences were considered when $p \leq 0.05$, and were derived from Student's $t$-test and ANOVA.

\section{Results}

Noncalcemic vitamin D hydroxyderivatives exhibit antitumor effects. The MTS assay, which assesses metabolic activity in a $2 \mathrm{D}$ environment as an index of proliferation, and the spheroid assay, which assesses cell viability in a $3 \mathrm{D}$ environment, were used to investigate the effects of the vitamin D hydroxyderivatives on CAL-27 cells. Spheroid assays help mimic solid tumor characteristics, such as anchorageindependent growth, that are seen in vivo and are needed for tumor progression (33). A dose-dependent reduction in CAL-27 proliferation was seen with both $20(\mathrm{OH}) \mathrm{D}_{3}$ and $1,20(\mathrm{OH})_{2} \mathrm{D}_{3}$ at levels similar to those of $25(\mathrm{OH}) \mathrm{D}_{3}$ and $1,25(\mathrm{OH})_{2} \mathrm{D}_{3}$ (Figure $1)$. The incubation of cells with $20(\mathrm{OH}) \mathrm{D}_{3}$ also significantly reduced spheroid formation but the effect was slightly lower than that of $1,25(\mathrm{OH})_{2} \mathrm{D}_{3}$ (Figure 2).

$20(\mathrm{OH}) \mathrm{D}_{3}$ and $1,2 \mathrm{O}(\mathrm{OH})_{2} \mathrm{D}_{3}$ up-regulate VDR expression. VDR expression was up-regulated after incubation with secosteroids for $3 \mathrm{~h}$ (Figure 3A). 1 $\alpha$-Hydroxylation potentiated 


\section{GLI1 staining}
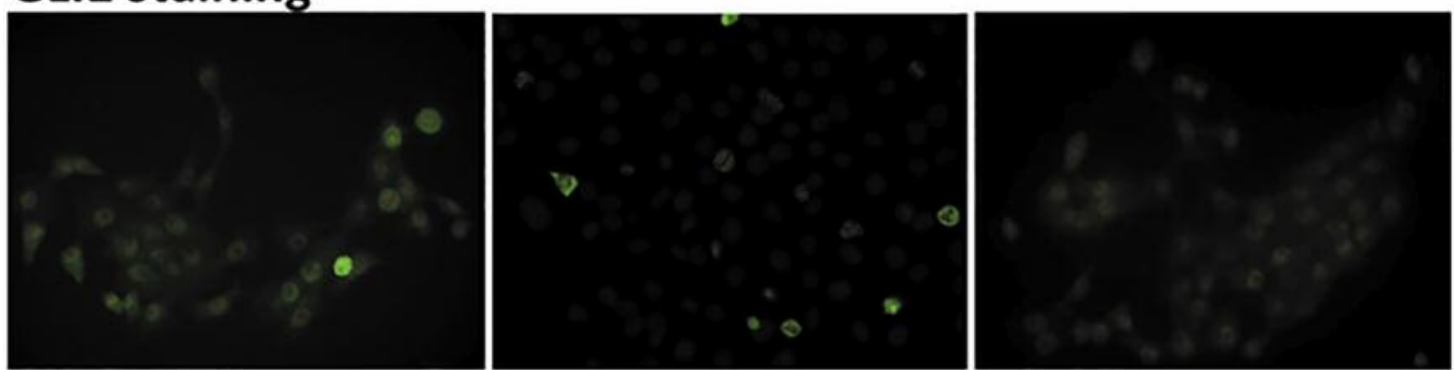

Ethanol

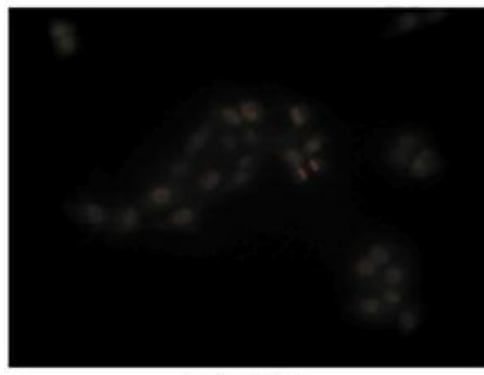

$25(\mathrm{OH}) \mathrm{D}_{3}$
$20(\mathrm{OH}) \mathrm{D}_{3}$

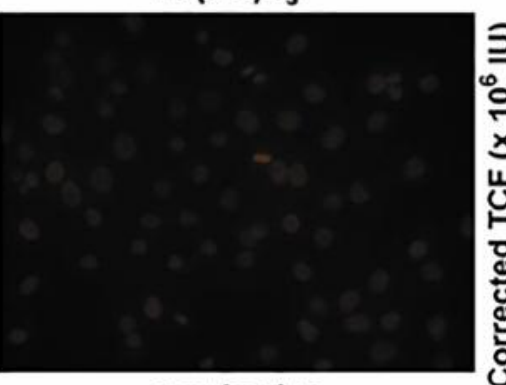

$1,25(\mathrm{OH})_{2} \mathrm{D}_{3}$
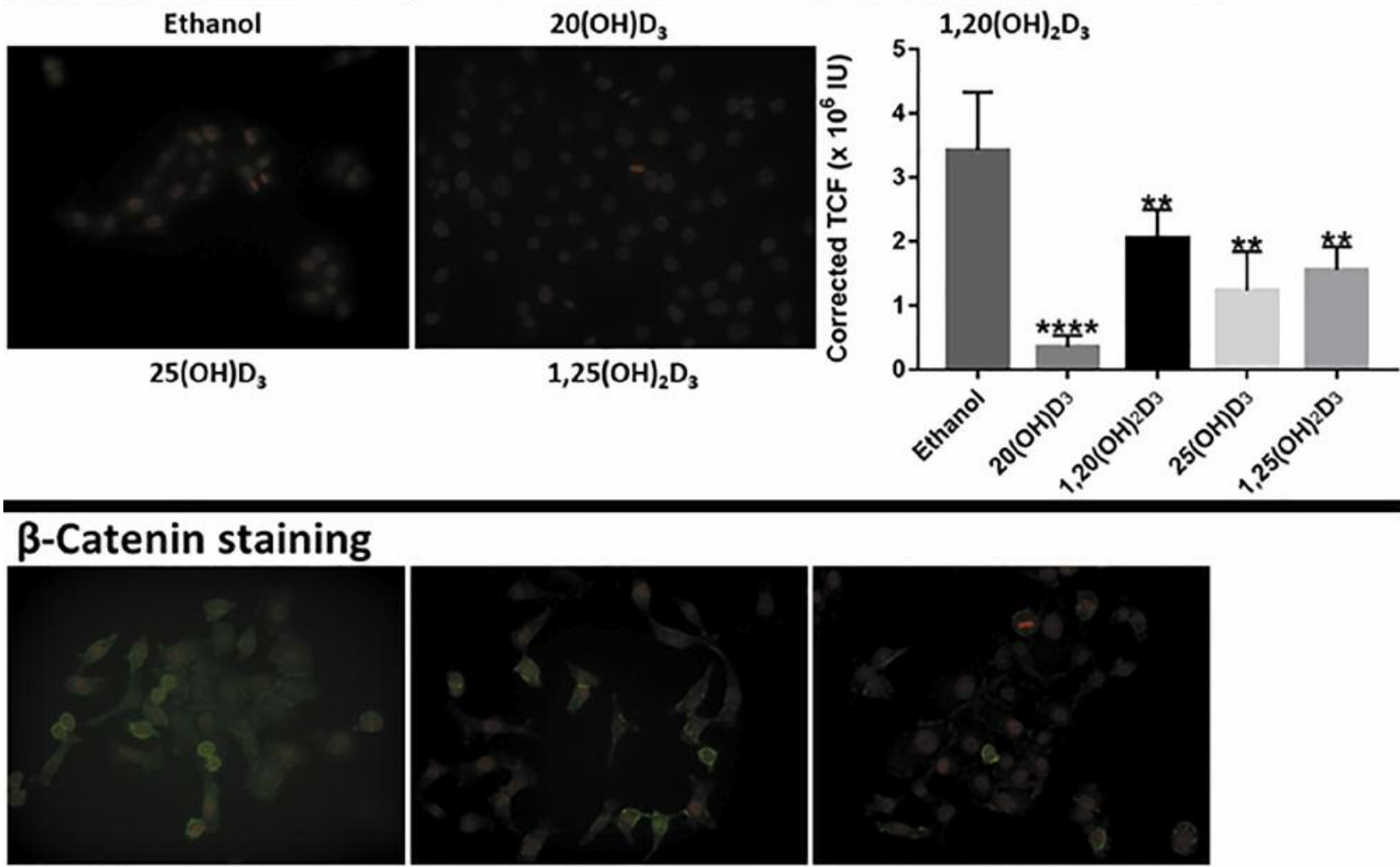

Ethanol

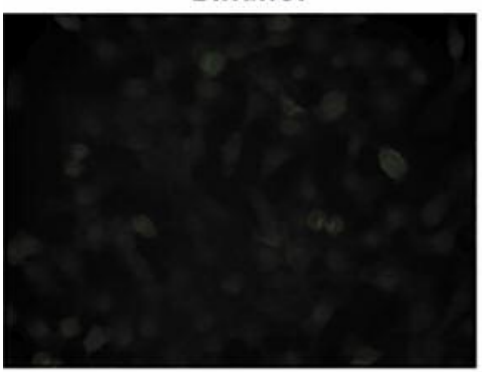

$25(\mathrm{OH}) \mathrm{D}_{3}$

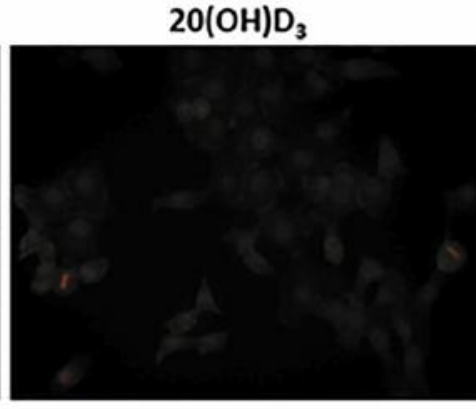

$1,25(\mathrm{OH})_{2} \mathrm{D}_{3}$

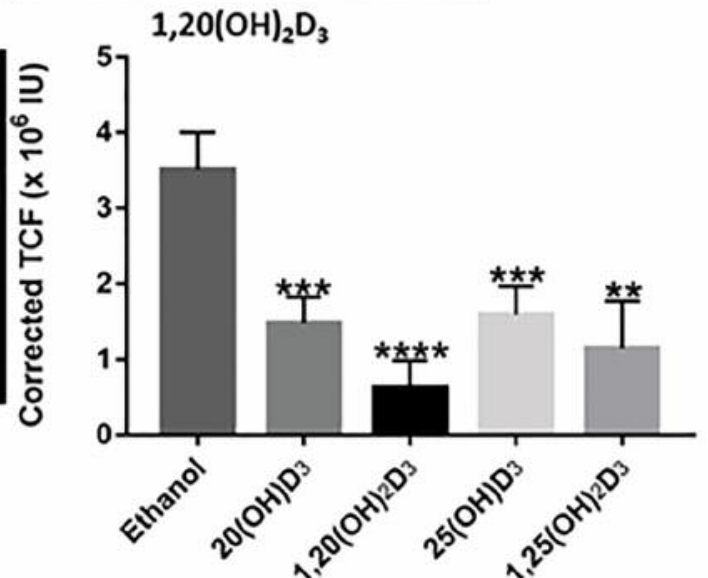

Figure 4. Immunofluorescent staining (green) of $\beta$-catenin and glioma-associated oncogene 1 (GLI1) in CAL-27 cells treated with hydroxyvitamin $D_{3}$ derivatives (10-7 M for 24 hours) with propidium iodide (red) as counterstain. For both GLII and $\beta$-catenin, the bottom right panels shows the quantitation of florescence staining for treatment with the individual secosteroids shown in the other panels. TCF: Total cell fluorescence. Significantly different at: ${ }^{* *} p \leq 0.01, * * * p \leq 0.001$, and $* * * * p \leq 0.0001$ by Student's $t$-test. 
this effect since both $1,20(\mathrm{OH})_{2} \mathrm{D}_{3}$ and $1,25(\mathrm{OH})_{2} \mathrm{D}_{3}$ cause markedly higher levels of VDR to be expressed when compared to their respective precursors, $20(\mathrm{OH}) \mathrm{D}_{3}$ and $25(\mathrm{OH}) \mathrm{D}_{3}$.

Novel secosteroids down-regulate nuclear translocation of GLII and $\beta$-catenin. GLI1, a nuclear factor involved in the hedgehog signaling pathway, was down-regulated after incubation with $20(\mathrm{OH}) \mathrm{D}_{3}$ or with $1,20(\mathrm{OH})_{2} \mathrm{D}_{3}$ for $24 \mathrm{~h}$ (Figure 4). Nuclear accumulation of GLI1 is required for activation of its downstream target genes. Western blot analysis revealed a decrease in GLI1 level in the nucleus and a corresponding increase in GLI1 level in the cytoplasm after treatment with vitamin D hydroxyderivatives (Figure 3B). The effect of $20(\mathrm{OH}) \mathrm{D}_{3}$ on GLI1 was greater than the effect of $1,25(\mathrm{OH})_{2} \mathrm{D}_{3}$ based on a comparison of levels by immunofluorescence (Figure 4). Similarly, $\beta$-catenin is translocated from the cytoplasm to the nucleus, where it serves to activate the transcription of $\mathrm{WNT} / \beta$-catenin target genes. Lower levels of $\beta$-catenin were observed by immunofluorescence (Figure 4) after treatment with the novel secosteroids for $24 \mathrm{~h}$ and a lower level was also observed in the nuclear fraction by western blot analysis (Figure 3A). Furthermore, increased levels of phospho- $\beta$ catenin were observed in the nuclear fraction after treatment with the secosteroids (Figure 3B). Phosphorylation of $\beta$ catenin triggers ubiquitination by E3 ubiquitin ligases and this process marks $\beta$-catenin for proteasome-mediated degradation (34).

\section{Discussion}

Nonclassical noncalcemic vitamin D hydroxyderivatives, $20(\mathrm{OH}) \mathrm{D}_{3}$ and $1,20(\mathrm{OH})_{2} \mathrm{D}_{3}$, demonstrated dose-dependent antitumor activity against human OSCC cells at levels comparable to those of the classical vitamin D hydroxyderivatives, $25(\mathrm{OH}) \mathrm{D}_{3}$ and $1,25(\mathrm{OH})_{2} \mathrm{D}_{3} \cdot 20(\mathrm{OH}) \mathrm{D}_{3}$ and $1,20(\mathrm{OH})_{2} \mathrm{D}_{3}$ also up-regulated VDR expression, with the presence of the $1 \alpha$-hydroxy group potentiating this effect. Previously, it was shown that $20(\mathrm{OH}) \mathrm{D}_{3}$ and $1,20(\mathrm{OH})_{2} \mathrm{D}_{3}$ have similar antiproliferative activity against human SKMel188 melanoma cells (35). However, $1,20(\mathrm{OH})_{2} \mathrm{D}_{3}$ had significantly more activity against normal melanocytes and it inhibited dendrite formation (36), whereas $20(\mathrm{OH}) \mathrm{D}_{3}$ did not. While $1 \alpha$-hydroxylation may potentiate the biological effect of $20(\mathrm{OH}) \mathrm{D}_{3}$, it also increases its calcemic effect (26). This is consistent with the observation by Holick and colleagues that $1 \alpha$-hydroxylation appears necessary for the physiological role of $1,25(\mathrm{OH})_{2} \mathrm{D}_{3}$ in calcium regulation (37).

This study demonstrates that noncalcemic vitamin D hydroxyderivatives inhibit the sonic hedgehog signaling pathway, as well as the $\mathrm{WNT} / \beta$-catenin signaling pathway. This is evident from the lower levels of their downstream transcription factors, GLI1 and $\beta$-catenin, after incubation with $20(\mathrm{OH}) \mathrm{D}_{3}$ or $1,20(\mathrm{OH})_{2} \mathrm{D}_{3}$ (Figure 4). Furthermore, the nuclear translocation of GLI1 and $\beta$-catenin was also downregulated (Figure 3). Schneider and colleagues reported in their study of adult tongue epithelium that SHH represses $\beta$ catenin transcriptional activity, and posited that smoothened (SMO) may inhibit nuclear $\beta$-catenin activity (38). Other studies have confirmed crosstalk between these two pathways and found that common modulators, such as Kirsten rat sarcoma viral oncogene homolog, phosphatase and tensin homolog, and p53, were involved in their regulation (39).

The inhibition of the growth of human OSCC cells by noncalcemic vitamin $\mathrm{D}$ analogs is in alignment with prior results documenting the activity of $1,25(\mathrm{OH})_{2} \mathrm{D}_{3}$ against oral squamous cell carcinoma. Noncalcemic CYP11A1-derived vitamin $\mathrm{D}$ hydroxyderivatives, $20(\mathrm{OH}) \mathrm{D}_{3}$ and $1,20(\mathrm{OH})_{2} \mathrm{D}_{3}$, seem to have antitumor activities against OSCC comparable to those of $25(\mathrm{OH}) \mathrm{D}_{3}$ and $1,25(\mathrm{OH})_{2} \mathrm{D}_{3}$. Furthermore, their activities against the hedgehog signaling pathway and the WNT/ $\beta$-catenin signaling pathway provide insight for a possible drug target for treatment of OSCC.

\section{Conflicts of Interest}

The Authors have no conflicts of interest to declare.

\section{Authors' Contributions}

A.T.S. conceived the study, designed the experiments and analyzed the data with input from M.A. A.S.W.O., T.K., A.A.B. and G.B. performed the experiments and analyzed the data. Z.J. provided technical guidance and analyzed the data. R.C.T. synthesized the novel noncalcemic hydroxyderivatives. A.S.W.O. wrote the article under A.T.S.'s supervision with input from all other Authors.

\section{Acknowledgements}

This work was supported in part by NIH grants 1R01AR07300401A1 and R01AR071189-01A1 and by a VA merit grant (no. 1I01BX004293-01A1) to A.T.S. The study was also supported by Fulbright grant (no.18-21-04/2018) to G.B.

\section{References}

1 Warnakulasuriya S: Global epidemiology of oral and oropharyngeal cancer. Oral Oncology 45: 309-316, 2009. PMID: 18804401. DOI: 10.1016/j.oraloncology.2008.06.002

2 PDQ Screening and Prevention Editorial Board: Oral Cavity, Pharyngeal, and Laryngeal Cancer Prevention (PDQ $\left.{ }^{\circledR}\right)$ : Health Professional Version. In: PDQ Cancer Information Summaries. Bethesda (MD), National Cancer Institute (USA), 2002. PMID: 26389416.

3 Weatherspoon DJ, Chattopadhyay A, Boroumand S and Garcia I: Oral cavity and oropharyngeal cancer incidence trends and disparities in the United States: 2000-2010. Cancer Epidemiol 39: 497-504, 2015. PMID: 25976107. DOI: 10.1016/j.canep. 2015.04.007 
4 Feller L and Lemmer J: Oral squamous cell carcinoma: Epidemiology, clinical presentation and treatment. J Cancer Ther 03: 263-268, 2012. DOI: 10.4236/jct.2012.34037

5 Jiang L, Ji N, Zhou Y, Li J, Liu X, Wang Z, Chen Q and Zeng $\mathrm{X}$ : CAL-27 is an oral adenosquamous carcinoma cell line. Oral Oncol 45: e204-207, 2009. PMID: 19631575. DOI: 10.1016/j.oraloncology.2009.06.001

6 Gioanni J, Fischel J-L, Lambert J-C, Demard F, Mazeau C, Zanghellini E, Ettore F, Formento P, Chauvel P, Lalanne C-M and Courdi A: Two new human tumor cell lines derived from squamous cell carcinomas of the tongue: Establishment, characterization and response to cytotoxic treatment. Eur J Canc Clin Oncol 24: 1445-1455, 1988. PMID: 3181269. DOI:10.1016/0277-5379(88)90335-5

7 Vermorken JB, Trigo J, Hitt R, Koralewski P, Diaz-Rubio E, Rolland F, Knecht R, Amellal N, Schueler A and Baselga J: Open-label, uncontrolled, multicenter phase II study to evaluate the efficacy and toxicity of cetuximab as a single agent in patients with recurrent and/or metastatic squamous cell carcinoma of the head and neck who failed to respond to platinum-based therapy. J Clin Oncol 25: 2171-2177, 2007. PMID: 17538161. DOI: 10.1200/JCO.2006.06.7447

8 Rothenberg SM and Ellisen LW: The molecular pathogenesis of head and neck squamous cell carcinoma. J Clin Invest 122: 1951-1957, 2012. PMID: 22833868. DOI: 10.1172/JCI59889

9 Kuroda H, Kurio N, Shimo T, Matsumoto K, Masui M, Takabatake K, Okui T, Ibaragi S, Kunisada Y, Obata K, Yoshioka N, Kishimoto K, Nagatsuka H and Sasaki A: Oral squamous cell carcinoma-derived sonic hedgehog promotes angiogenesis. Anticancer Res 37: 6731-6737, 2017. PMID: 29187450. DOI: 10.21873/anticanres.12132

10 Srinath S, Iyengar AR and Mysorekar V: Sonic hedgehog in oral squamous cell carcinoma: An immunohistochemical study. J Oral Maxillofac Pathol 20: 377-383, 2016. PMID: 27721600. DOI: 10.4103/0973-029X.190906

11 Iwai S, Yonekawa A, Harada C, Hamada M, Katagiri W, Nakazawa $\mathrm{M}$ and Yura Y: Involvement of the WNT- $\beta$-catenin pathway in invasion and migration of oral squamous carcinoma cells. Int J Oncol 37: 1095-103, 2010. PMID: 20878057. DOI: 10.3892/ijo_00000761

12 Bijian K, Mlynarek AM, Balys RL, Jie S, Xu Y, Hier MP, Black MJ, Di Falco MR, LaBoissiere S and Alaoui-Jamali MA: Serum proteomic approach for the identification of serum biomarkers contributed by oral squamous cell carcinoma and host tissue microenvironment. J Proteome Res 8: 2173-2185, 2009. PMID: 19284786. DOI: $10.1021 /$ pr800979e

13 Zeljic K, Supic G, Stamenkovic Radak M, Jovic N, Kozomara $\mathrm{R}$ and Magic Z: Vitamin D receptor, CYP27B1 and CYP24A1 genes polymorphisms association with oral cancer risk and survival. J Oral Pathol Med 41: 779-787, 2012. PMID: 22612324. DOI: 10.1111/j.1600-0714.2012.01164.x

14 Grimm M, Cetindis M, Biegner T, Lehman M, Munz A, Teriete $\mathrm{P}$ and Reinert S: Serum vitamin D levels of patients with oral squamous cell carcinoma (OSCC) and expression of vitamin D receptor in oral precancerous lesions and OSCC. Med Oral Patol Oral Cir Bucal 20: e188-195, 2015. PMID: 25662556. DOI: 10.4317/medoral.20368

15 Shintani T, Rosli SNZ, Takatsu F, Choon YF, Hayashido Y, Toratani S, Usui E and Okamoto T: Eldecalcitol (ED-71), an analog of $1 \alpha, 25$-dihydroxyvitamin $\mathrm{D}_{3}$ as a potential anti-cancer agent for oral squamous cell carcinomas. J Steroid Biochem Mol Biol 164: 7984, 2016. PMID: 26444325. DOI: 10.1016/j.jsbmb.2015.09.043

16 Huang Z, Zhang Y, Li H, Zhou Y, Zhang Q, Chen R, Jin T, Hu K, Li S, Wang Y, Chen W and Huang Z: Vitamin D promotes the cisplatin sensitivity of oral squamous cell carcinoma by inhibiting LCN2-modulated NF-kB pathway activation through RPS3. Cell Death Dis 10: 936, 2019. PMID: 31819048. DOI: 10.1038/s41419-019-2177-x

17 Zbytek B, Janjetovic Z, Tuckey RC, Zmijewski MA, Sweatman TW, Jones E, Nguyen MN and Slominski AT: 20Hydroxyvitamin $D_{3}$, a product of vitamin $D_{3}$ hydroxylation by cytochrome P450scc, stimulates keratinocyte differentiation. J Invest Dermatol 128: 2271-2280, 2008. PMID: 18368131. DOI: $10.1038 /$ jid. 2008.62

18 Janjetovic Z, Zmijewski MA, Tuckey RC, DeLeon DA, Nguyen MN, Pfeffer LM and Slominski AT: 20-Hydroxycholecalciferol, product of vitamin $\mathrm{D}_{3}$ hydroxylation by $\mathrm{P} 450 \mathrm{scc}$, decreases NF$\mathrm{KB}$ activity by increasing IkB $\alpha$ levels in human keratinocytes. PLoS One 4: e5988, 2009. PMID: 19543524. DOI: 10.1371/ journal.pone.0005988

19 Janjetovic Z, Tuckey RC, Nguyen MN, Thorpe EM and Slominski AT: 20,23-dihydroxyvitamin $\mathrm{D}_{3}$, novel P450scc product, stimulates differentiation and inhibits proliferation and NF-kB activity in human keratinocytes. J Cell Phys: 223(1): 3648, 2010. PMID: 20020487. DOI: 10.1002/jcp.21992

20 Slominski AT, Kim T-K, Shehabi HZ, Semak I, Tang EKY, Nguyen MN, Benson HAE, Korik E, Janjetovic Z, Chen J, Yates CR, Postlethwaite A, Li W and Tuckey RC: In vivo evidence for a novel pathway of vitamin $\mathrm{D}_{3}$ metabolism initiated by $\mathrm{P} 450 \mathrm{scc}$ and modified by CYP27B1. FASEB J 26: 3901-3915, 2012. PMID: 22683847. DOI: 10.1096/fj.12-208975

21 Slominski AT, Kim T-K, Li W, Postlethwaite A, Tieu EW, Tang EKY and Tuckey RC: Detection of novel CYP11A1-derived secosteroids in the human epidermis and serum and pig adrenal gland. Sci Rep 5: 14875, 2015. PMID: 26445902. DOI: 10.1038/srep14875

22 Slominski AT, Li W, Kim T-K, Semak I, Wang J, Zjawiony JK and Tuckey RC: Novel activities of CYP11A1 and their potential physiological significance. J Steroid Biochem Mol Biol 151: 25 37, 2015. PMID: 25448732. DOI: 10.1016/j.jsbmb.2014.11.010

23 Tuckey RC, Cheng CYS and Slominski AT: The serum vitamin D metabolome: What we know and what is still to discover. $\mathrm{J}$ Steroid Biochem Mol Biol, 2018. PMID: 30205156. DOI: 10.1016/j.jsbmb.2018.09.003

24 Slominski AT, Kim T-K, Li W, Yi A-K, Postlethwaite A and Tuckey RC: The role of CYP11A1 in the production of vitamin $\mathrm{D}$ metabolites and their role in the regulation of epidermal functions. J Steroid Biochem Mol Biol 144 Pt A: 28-39, 2014. PMID: 24176765. DOI: 10.1016/j.jsbmb.2013.10.012

25 Slominski AT, Kim T-K, Li W and Tuckey RC: Classical and non-classical metabolic transformation of vitamin D in dermal fibroblasts. Exp Dermatol 25: 231-232, 2016. PMID: 26440881. DOI: $10.1111 /$ exd.12872

26 Slominski AT, Janjetovic Z, Fuller BE, Zmijewski MA, Tuckey RC, Nguyen MN, Sweatman T, Li W, Zjawiony J, Miller D, Chen TC, Lozanski G and Holick MF: Products of vitamin $\mathrm{D}_{3}$ or 7-dehydrocholesterol metabolism by cytochrome P450scc show anti-leukemia effects, having low or absent calcemic activity. PLoS One 5: e9907, 2010. PMID: 20360850. DOI: 10.1371/journal.pone.0009907 
27 Wang J, Slominski A, Tuckey RC, Janjetovic Z, Kulkarni A, Chen J, Postlethwaite AE, Miller D and Li W: 20hydroxyvitamin $\mathrm{D}_{3}$ inhibits proliferation of cancer cells with high efficacy while being non-toxic. Anticancer Res 32: 739746, 2012. PMID: 22399586.

28 Slominski AT, Kim T-K, Janjetovic Z, Tuckey RC, Bieniek R, Yue J, Li W, Chen J, Nguyen MN, Tang EKY, Miller D, Chen TC and Holick M: 20-Hydroxyvitamin $\mathrm{D}_{2}$ is a noncalcemic analog of vitamin $\mathrm{D}$ with potent antiproliferative and prodifferentiation activities in normal and malignant cells. Am J Physiol, Cell Physiol 300: C526-541, 2011. PMID: 21160030. DOI: 10.1152/ajpcell.00203.2010

29 Tuckey RC, Li W, Zjawiony JK, Zmijewski MA, Nguyen MN, Sweatman T, Miller D and Slominski A: Pathways and products for the metabolism of vitamin $\mathrm{D}_{3}$ by cytochrome P450scc. FEBS J 275: 2585-2596, 2008. PMID: 18410379. DOI: 10.1111/j.17424658.2008.06406.x

30 Tuckey RC, Janjetovic Z, Li W, Nguyen MN, Zmijewski MA, Zjawiony $\mathrm{J}$ and Slominski A: Metabolism of 1alpha-hydroxyvitamin $\mathrm{D}_{3}$ by cytochrome $\mathrm{P} 450$ scc to biologically active 1alpha,20dihydroxyvitamin $\mathrm{D}_{3}$. J Steroid Biochem Mol Biol 112: 213-219, 2008. PMID: 19000766. DOI: 10.1016/j.jsbmb.2008.10.005

31 Li W, Chen J, Janjetovic Z, Kim T-K, Sweatman T, Lu Y, Zjawiony J, Tuckey RC, Miller D and Slominski A: Chemical synthesis of 20Shydroxyvitamin $\mathrm{D}_{3}$, which shows antiproliferative activity. Steroids 75 : 926-935, 2010. PMID: 20542050. DOI: 10.1016/j.steroids.2010.05.021

32 Johnson S, Chen $\mathrm{H}$ and Lo P-K: In vitro tumorsphere formation assays. Bio Protoc 3: e325, 2013. PMID: 27500184. DOI: $10.21769 /$ bioprotoc 325

33 Takagi A, Watanabe M, Ishii Y, Morita J, Hirokawa Y, Matsuzaki $\mathrm{T}$ and Shiraishi T: Three-dimensional cellular spheroid formation provides human prostate tumor cells with tissue-like features. Anticancer Res 27: 45-53, 2007. PMID: 17352215.
34 Shang S, Hua F and Hu Z-W: The regulation of $\beta$-catenin activity and function in cancer: therapeutic opportunities. Oncotarget 8(20): 33972-33989, 2017. PMID: 28430641. DOI: 10.18632 /oncotarget. 15687

35 Skobowiat C, Oak ASW, Kim T-K, Yang CH, Pfeffer LM, Tuckey RC and Slominski AT: Noncalcemic 20-hydroxyvitamin $\mathrm{D}_{3}$ inhibits human melanoma growth in in vitro and in vivo models. Oncotarget 8: 9823-9834, 2017. PMID: 28039464. DOI: 10.18632/oncotarget.14193

36 Slominski AT, Janjetovic Z, Kim T-K, Wright AC, Grese LN, Riney SJ, Nguyen MN and Tuckey RC: Novel vitamin D hydroxyderivatives inhibit melanoma growth and show differential effects on normal melanocytes. Anticancer Res 32: 3733-3742, 2012. PMID: 22993313.

37 Holick MF, Garabedian M, Schnoes HK and DeLuca HF: Relationship of 25-hydroxyvitamin $\mathrm{D}_{3}$ side chain structure to biological activity. J Biol Chem 250: 226-230, 1975. PMID: 1141205

38 Schneider FT, Schänzer A, Czupalla CJ, Thom S, Engels K, Schmidt MHH, Plate KH and Liebner S: Sonic hedgehog acts as a negative regulator of $\beta$-catenin signaling in the adult tongue epithelium. Am J Pathol 177: 404-414, 2010. PMID: 20508033. DOI: 10.2353/ajpath.2010.091079

39 Song L, Li Z-Y, Liu W-P and Zhao M-R: Crosstalk between WNT/ $\beta$-catenin and Hedgehog/Gli signaling pathways in colon cancer and implications for therapy. Cancer Biol Ther 16: 1-7, 2015. PMID: 25692617. DOI: 10.4161/15384047.2014.972215

Received February 29, 2020

Revised March 21, 2020

Accepted March 27, 2020 